\title{
BRAIN SCALE (PSORA CEREBRIFORMIS), A RARE LICHEN IN SASKATCHEWAN: ASECOND RECORD
}

BERNARD DE VRIES, 29 Hogan Place, Emerald Park, SK, S4L 1C1; E-mail: <bdevries@accesscomm.ca>

Brain Scale (Psora cerebriformis) belongs to the Interior Basin distribution centre as part of the western North American and Greater Sonoran Desert geographic distribution pattern, ranging north into the semiarid grasslands of southwestern Saskatchewan, Alberta, and British Columbia. ${ }^{1,8}$ Blushing Scale ( $P$. decipiens) has a broader distribution, occurring in the southern grasslands of Saskatchewan, Alberta, and British Columbia and arctic regions. ${ }^{1,9}$ The possibility that Brain Scale could occur in the grasslands of southwestern Saskatchewan came to my attention after examining a geographical distribution map for the southern grasslands of Saskatchewan, Alberta, and British Columbia. ${ }^{1}$

This information raised the question of whether a specimen could be located to verify the presence of Brain Scale in southwestern Saskatchewan. Subsequent inquiries at various herbaria, including the Canadian Museum of Nature Herbarium in Ottawa, Ontario, and searches through the literature met with negative results until it was determined that Brain Scale was in fact deposited in the Canadian Museum of Nature Herbarium; but had been misidentified ( $R$. Wright, Saskatchewan Ministry of Tourism, Parks, Culture, and Sports, personal communication, 2008). The specimen (collection number 630504) was collected on 18 April 1963 on an eroded slope near Fosterton, northwest of Swift Current, Saskatchewan, elevation $2750 \mathrm{ft}$ (Fig. 1). It was misidentified as Lecidea decipiens (Ehrh.) Ach. by J. Looman, who made extensive studies of the grassland lichen flora during his tenure as a range ecologist at the Federal Research Station at Swift Current. ${ }^{4,5,6,7}$ The specimen was subsequently revised to $P$. decipiens (synonym: Lecidea decipiens; Blushing Scale) in 1977, and again to P. cerebriformis W.A. Weber in 2008. Originally the specimen was accessed as Lecidea \#1000 from staff collections (14 June 1966), but upon revision it was accessed as CANL 4913 (P.Y. Wong, Canadian Museum of Nature, personal communication 2008), suggesting that Looman did not deposit this lichen into the Canadian Museum of Nature Herbarium.

This information prompted a request for a loan so that the specimen could be re-examined and compared to specimens of Brain Scale from Arizona (Fig. 2a, see inside back cover) and Blushing Scale from Saskatchewan (Fig. 2b, see inside back cover), both in the author's private herbarium and in the published literature. ${ }^{1,8}$ 


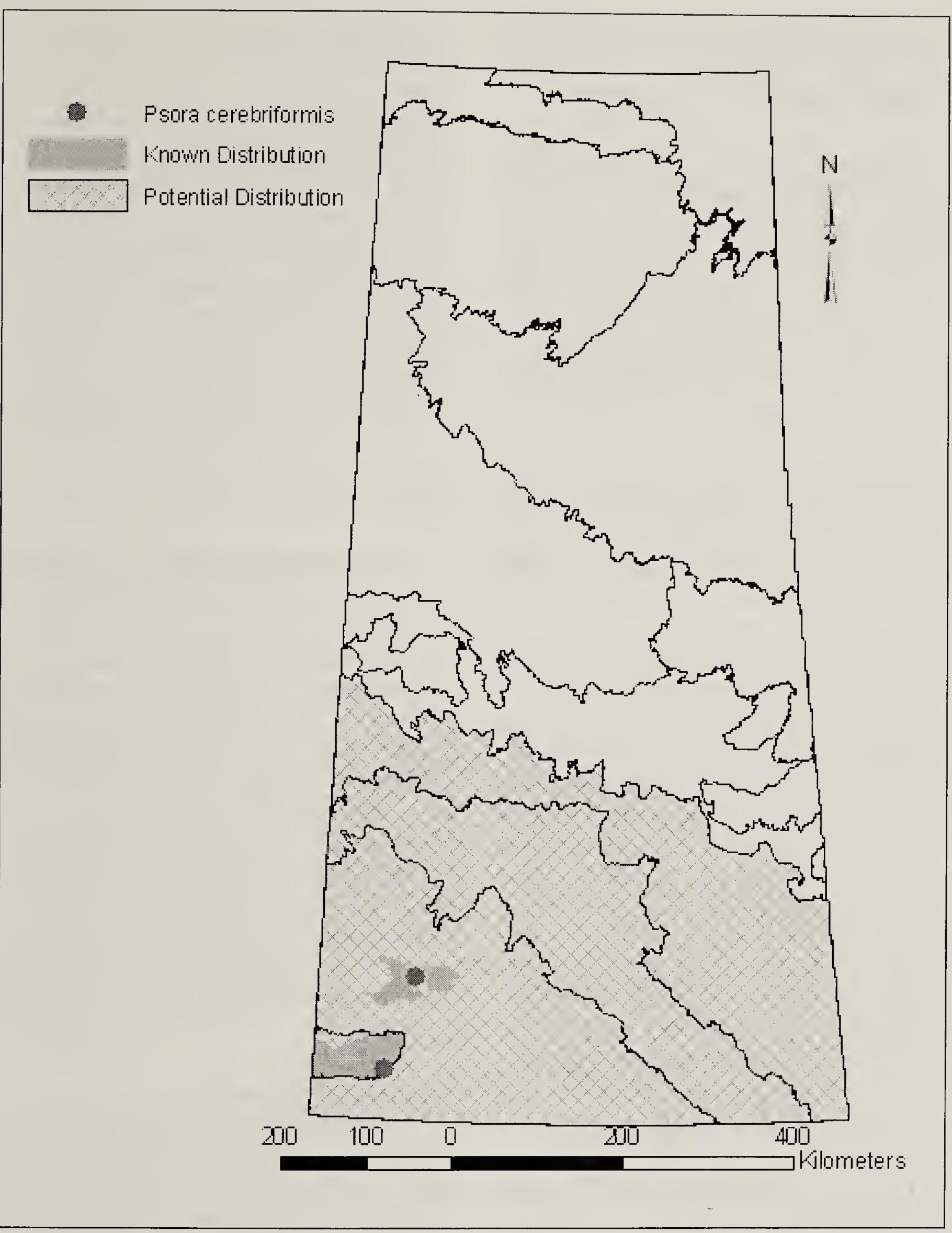

Figure 1. Ecoregions within ecozones in Saskatchewan. Dots show known occurrences, gray areas show potential locations, and cross-hatched areas show the potential distribution of Brain Scale.

Upon examination of the specimen, it became apparent that the material was indeed Psora cerebriformis (Brain Scale), but could be mistaken for Blushing Scale. The possibility of misidentification can partially be explained by similarities between
Brain Scale and Blushing Scale on dry, calcareous soils in the Xanthoparmelia chlorochroa (Tumbleweed shield lichen) association (a climax unit dominated by one or more species having the life-form characteristic of the greater 
climax [formation] unit to which the association belongs $)^{6,7,9}$ of southern Saskatchewan and Alberta.

Comparing the specimen to Brain Scale from Arizona and Blushing Scale from Saskatchewan, distinct anatomical and morphological differences were apparent. The vegetative body (thallus) of Brain Scale is usually pale yellowish-brown to olive-brown or gray, while Blushing Scale is orange-brown to brick-red or pink (hence its common name), although upon aging or decaying it can become dull rusty brown. The vegetative body of Brain Scale is also commonly strongly convex, but at times has rather flat scale-like lobes (squamules) similar to those in Blushing Scale, which are always flat with frayed, upturned white margins. Another characteristic differentiating these species is that Brain Scale mostly has a fissured vegetative body resembling a brain and is often heavily coated with a white powdery deposit (pruina), which gives it a characteristic 'frosted' appearance. Blushing Scale lacks such fissures but can be partially 'frosted.' Both species bear black marginal fruiting bodies. Another explanation for the poor state of the Fosterton specimen could be that the site of discovery is at the northern limit of its known geographic range.

The discovery site of Brain Scale at Fosterton is about $2,500 \mathrm{~km}$ north of Arizona, where is quite common. ${ }^{8} \mathrm{~A}$ recent (5-6 August 2008) survey of the area where Looman collected this specimen did not result in additional records of this elusive and very rare lichen. This does not rule out the possibility that the species could still be found in this range of native hills, or in similar locations in the more semiarid regions of southern Saskatchewan.
I made a second discovery ( 16 September 2008) of this elusive lichen (Fig. 2c, see inside back cover) on a northwest-facing upper slope with dry native prairie vegetation on calcareous soil, a few kilometers east of Eastend, about $100 \mathrm{~km}$ southwest of Fosterton. This suggests that within these known localities, the possibility exists of finding additional specimens through more intensive field surveys. These two collections undoubtedly will be of interest to those documenting and conserving rare and endangered lichen species of which little is known for Saskatchewan.

The preliminary ranking for lichens is based on the number of known occurrences. As such, Brain Scale is ranked S1 ("extremely rare": five occurrences or only a few individuals known $)^{2}$ for Saskatchewan and southern Alberta, ${ }^{3}$ while its ranking in southern British Columbia is unknown. In order to increase our knowledge of the Saskatchewan lichen flora, ongoing and extensive field studies should be done to enhance the discovery of additional rare or endangered species, especially in the southern native grasslands.

\section{Acknowledgements}

I thank Nature Saskatchewan (Member Initiatives Grant), and the Ministry of Environment, Conservation Data Centre, for financial support for this rare and endangered lichen study. Special thanks to Pak Yau Wong and Jennifer Doubt for allowing a special loan of the specimen; to Rob Wright for helping in locating herbaria; and to Linda Krieger for showing a keen interest in this survey and for being a valued assistant.

1. BRODO, I.M., S.D. SHARNOFF, and S. SHARNOFF. 2001. Lichens of North America. Yale University Press, New Haven, CT, USA. 
2. DE VRIES, B. 2007. Saskatchewan Rare and Endangered Lichens. Preliminary Lichen Ranking List. Unpublished.

3. GOULD, J. 2000. Alberta Natural Heritage Information Centre Preliminary Lichen Tracking List. Alberta Environment, Edmonton, AB.

4. LOOMAN, J. 1962. Some lichens of Saskatchewan. The Bryologist 65: 294-304.

5. LOOMAN, J. 1964a. Ecology of lichens and bryophyte communities in Saskatchewan. Ecology 45(3): 481-491.

6. LOOMAN, J. 1964b. The distribution of some lichen communities in the prairie provinces and adjacent parts of the Great Plains. The Bryologist $67(2): 209-224$

7. LOOMAN, J. 1969. Squamarina crassa in Saskatchewan. The Bryologist 72(3): 412-413.

8. NASH, T.H. III, B.D. RYAN, C. GRIES, and F. BUNGARTZ 2002. Lichen Flora of the Greater Sonoran Desert region. Volume I (The Pyrenolichens and Most of the Squamulose and Macro Lichens). Lichens Unlimited, Arizona State University, Tempe, AZ, USA.

9. POLUNIN, N. 1960. Introduction to Plant Geography. McGraw Hill Book Company, New York, Toronto, London.

\section{BIOLOGY OF DOWNY ARROW-WOOD (VIBURNUM RAFINESQUIANUM)}

TOM REAUME, 212 Sherburn Street, Winnipeg, MB, R3G 2K6; E-mail: <tj333reaume@yahoo.com>

\section{Introduction}

Downy Arrow-wood (Viburnum rafinesquianum [Schultes]) is a member of the honeysuckle family Caprifoliaceae. A rhizomatous, medium-sized native, this deciduous shrub is found in the eastern half of North America. It grows singly or in thickets along streams, in open woodlands, and on wooded rocky hillsides.

Ink drawings were made from plants in the field and from fresh specimens. The original drawings were donated to the Hunt Institute for Botanical Documentation, Pittsburgh, PA.

\section{Study}

This study took place in late 2005 and throughout 2006 in Winnipeg, Manitoba. It was initiated and funded by the author. The study area at $49^{\circ}$ 52.399; $97^{\circ} 14.073$ and 235 m elevation was an open Bur Oak (Quercus macrocarpa) woods in Assiniboine Park. Bur Oak, the only oak in Manitoba, had an average diameter at breast height (dbh) of 18 (range: 232) $\mathrm{cm}(n=122)$. In three 96 by $2 \mathrm{~m}$ random transects, 43 oak trees each occupied an area of $13 \mathrm{~m}^{2}$.

Other vascular plants in the study area included Mountain Maple (Acer spicatum), Saskatoon Service-berry (Amelanchier alnifolia), Red-osier Dogwood (Cornus alba), American Hazelnut (Corylus americana), hawthorn (Crataegus spp.), Green Ash (Fraxinus pennsylvanica), Aspen Poplar (Populus tremuloides), European Buckthorn (Rhamnus cathartica), goldenrod (Solidago spp.), Poison Ivy (Toxicodendron rydbergii), and Nannyberry (Viburnum lentago).

\section{Morphology}

Plants were erect, with opposite branches and leaves. Before the first branches developed, young vegetative plants up to ca. $30 \mathrm{~cm}$ tall had two to several pairs of opposite, spreading leaves along the stem. Tall reproductive plants were somewhat leaning or nodding. Plant height and 